Original article

\title{
An Internationally Comparative Study of Immigration and Adolescent Emotional and Behavioral Problems: Effects of Generation and Gender
}

\author{
Gonneke W.J.M. Stevens, Ph.D. ${ }^{\text {a,* }}$, Sophie D. Walsh, Ph.D. ${ }^{b}$, Tim Huijts, Ph.D. ${ }^{\text {, }}$, Marlies Maes, M.Sc. ${ }^{\text {, }}$ \\ Katrine Rich Madsen, M.Sc. ${ }^{\text {, }}$, Franco Cavallo, Ph.D. ${ }^{\text {, }}$ and Michal Molcho, Ph.D. ${ }^{\mathrm{g}}$ \\ ${ }^{a}$ Utrecht Centre for Child and Adolescent Studies, Utrecht University, Utrecht, The Netherlands \\ ${ }^{\mathrm{b}}$ Department of Criminology, Bar Ilan University, Ramat Gan, Israel \\ ${ }^{\mathrm{c}}$ Centre for Primary Care and Public Health, Queen Mary University of London, London, United Kingdom \\ ${ }^{\mathrm{d}}$ Department of School Psychology and Child and Adolescent Development, KU Leuven, Leuven, Belgium \\ e National Institute of Public Health, University of Southern Denmark, København, Denmark \\ ${ }^{\mathrm{f}}$ Department of Public Health and Paediatrics, School of Medicine, University of Torino, Torino, Italy \\ ${ }^{\mathrm{g}}$ Health Promotion Research Centre, National University of Ireland, Galway, Ireland
}

Article history: Received December 9, 2014; Accepted July 16, 2015

Keywords: Immigration; Emotional and behavioral problems; International comparison; Immigrant generation; Gender

\section{A B S T R A C T}

Purpose: Although the potential consequences of immigration for adolescent problem behaviors have been addressed in many former studies, internationally comparative research is scarce. This study investigated the impact of immigration on four indicators of adolescents' emotional and behavioral problems in 10 countries, taking into account gender and immigrant generation as moderating factors. Methods: Analyses were based on data from 11-,13-, and 15-year-old adolescents participating in the Health Behavior in School-aged Children study in Denmark, Germany, Greece, Iceland, Ireland, Italy, the Netherlands, Spain, the United States, and Wales (total N =53,218).

Results: Both first- and second-generation immigrant adolescents reported higher levels of physical fighting and bullying and a lower life satisfaction than native adolescents, whereas second-generation immigrant adolescents reported more psychosomatic symptoms than native adolescents. Effect sizes varied considerable for the different outcomes, and similar effects were found for first- and secondgeneration immigrant adolescents. Differences in these indicators of emotional and behavioral problems between immigrant and native adolescents did not vary significantly with the receiving country. With two exceptions, effects of immigrant status were similar for boys and girls. Although no differences in psychosomatic symptoms were found between first-generation immigrant and native girls, first-generation immigrant boys reported less psychosomatic symptoms than native boys. Furthermore, both second-generation immigrant boys and girls reported higher levels of physical fighting than their native peers, but differences were more pronounced for boys than for girls.

Conclusions: Overall, the results of this study support a risk perspective on the impact of immigration on adolescent problem behaviors.

(c) 2015 Society for Adolescent Health and Medicine. All rights reserved.

\section{IMPLICATIONS AND} CONTRIBUTION

First- and secondgeneration immigrant adolescents show a higher risk of emotional and behavioral problems than their native peers. Similar results were found for adolescents growing up in 10 different countries and for boys and girls. Findings highlight that policymakers need to devise (additional) strategies of support for immigrant adolescents.
Conflicts of Interest: There are no potential conflicts of interest, real and perceived, for all the authors.

Disclaimer: Study sponsors did not have any role in the study design, data collection and analyses, interpretation of the data, the writing of the article, and the decision to submit the article.
* Address correspondence to: Gonneke W.J.M. Stevens, Ph.D., Utrecht Centre for Child and Adolescent Studies, Utrecht University, P.O. Box 80.140, 3508 TC Utrecht, The Netherlands.

E-mail address: g.w.j.m.stevens@uu.nl (G.W.J.M. Stevens). 
A rich body of literature has examined the impact of immigration on adolescent emotional and behavioral problems, showing more problems in some, but not all, immigrant populations [1]. Also, it is acknowledged that the situation of immigrant adolescents may vary greatly because of their specific ethnic background and of the receiving country they are brought up in [1-3]. However, internationally comparative research on immigration and adolescent emotional and behavioral problems is scarce, which makes it difficult to establish whether generalized conclusions about the impact of immigration throughout the western world are warranted. The few existing cross-national studies have mostly been conducted in a limited number of countries, examining nonrepresentative groups of adolescents and have not attempted to empirically test whether immigrant status effects vary according to the receiving countries investigated [4-7]. This study investigates the impact of immigration on emotional and behavioral problems in adolescents in nine European countries and in the United States, with a special focus on immigrant generation and gender.

Theories on the impact of immigration on problem behaviors have suggested both a risk and resilience perspective. The risk perspective focuses on the potential stress resulting from the process of migration, entailing, for instance, the loss of family and friends, customs, surroundings, and the need to adapt to a new cultural environment [8]. Asymmetric acculturation within families is a common pattern in which children acquire the receiving country's culture and language much faster than their parents. Together with financial, occupational, and social stressors as a consequence of migration, this sets the stage for intergenerational conflict and stress in migrant families [9]. The risk perspective also emphasizes that immigrants are frequently confronted with discrimination [10] which may negatively affect psychological functioning [11]. Thus, on the basis of the risk perspective, immigrant adolescents are expected to show more emotional and behavioral problems than their native peers.

In contrast, the resilience perspective argues that immigrant adolescents experience emotional and behavioral problems similarly to or even less than their native peers, a phenomenon referred to as the "immigrant paradox" [12]. This paradox has been explained by pointing to immigrants' strong ethnic support system, sense of family obligations, and academic motivation serving as a buffer against adolescent emotional and behavioral problems [13-15]. The immigrant paradox has been extended to relate to the notion of second-generation immigrants doing less well than the first-generation immigrants [16]. It may be that it is mainly the first-generation immigrant adolescents that have a strong ethnic support system [13]. Additionally, as secondgeneration immigrant adolescents may be more likely to pursue full participation in the receiving society than their first-generation immigrant peers, restrictive processes such as discrimination may be especially painful for adolescents belonging to this generation [17]. Thus, the impact of immigration on adolescent emotional and behavioral problems may be different for first- than for second-generation immigrants, with a more deleterious impact on the latter group. There is a lack of empirical research either supporting or rejecting this theoretical notion because former research has far from systematically distinguished between immigrant generations [1]. The few studies that have studied emotional and behavioral problems of first- and second-generation immigrant as compared with native adolescents have shown inconsistent findings [5,18-20].
The effect of immigration on adolescent emotional and behavioral problems may also vary with the adolescent's gender. Girls may be more vulnerable to the impact of immigration than boys, as socialization demands on immigrant boys and girls may vary considerably, with girls being more restricted regarding their autonomy and freedom of movement than boys [21]. Because parental socialization demands on immigrant girls may be discordant with these demands of the receiving country, friction in the parent-child relationship may occur [22]. Alternatively, boys may be more vulnerable to the impact of immigration than girls because immigrant parents often have stronger academic aspirations for their sons than for their daughters [23]. Combining these aspirations with the more frequently experienced school problems of immigrant boys than girls [24], immigrant boys may be more likely to experience stress and to show emotional and behavioral problems than immigrant girls. Some former research indeed indicates that the impact of immigration on adolescent emotional and behavioral problems may be different for boys and girls. However, it is unclear whether boys or girls are more vulnerable to the impact of immigration [24-29].

In this study, the impact of immigration on adolescent emotional and behavioral problems was investigated in a largescale cross-national study in nine European countries and the United States. Drawing on the resilience and the risk perspectives as well as previous research, lower, equally high, or higher levels of adolescent emotional and behavioral problems may be expected among immigrants compared with native adolescents. This study tested whether the effects of immigration varied according to (1) receiving country; (2) immigrant generation; and (3) gender. On the basis of the theoretical notions, differences in the impact of immigration for first- and second-generation immigrants were expected, with a more negative impact of immigration for the latter group. In addition, although the literature is inconclusive about the direction of gender-specific effects, a differential impact of immigration for boys and girls was expected.

\section{Methods}

\section{Participants and procedure}

The Health Behavior in School-Aged Children study is a crossnational study conducted every 4 years in the United States, Canada, and approximately 40 countries in Europe. The Health Behavior in School-Aged Children study collects data on the wellbeing and social environments of 11-, 13-, and 15-year-old adolescents. A standardized sampling method is used to ensure that all national samples are representative of all adolescent groups living in the country within the age range [30]. Cluster sampling is conducted in accordance with the structure of national education systems within each country. The primary sampling unit is the school class or the whole school where a sample frame of classes is not available. Data are collected anonymously using a questionnaire completed in the classroom. Adolescents filled out the questionnaire in the receiving country language, the language in which they were being educated. All participating countries and regions obtain institutional ethics approval. This study uses data from 2010 from 10 of the participating countries (Denmark, Germany, Greece, Iceland, Ireland, Italy, the Netherlands, Spain, the United States, and Wales). Table 1 indicates a variation in migration policies and attitudes toward 
Table 1

Indicators of migration context and associations between immigrant status, family affluence and emotional and behavioral problems in participating countries

\begin{tabular}{|c|c|c|c|c|c|c|c|c|c|c|c|c|c|}
\hline \multirow[t]{2}{*}{ Country } & \multirow{2}{*}{$\begin{array}{l}\text { Ethnic background } \\
\text { largest three } \\
\text { immigrant groups }\end{array}$} & \multirow[t]{2}{*}{$\begin{array}{l}\text { MIPEX total } \\
(0-100)\end{array}$} & \multirow{2}{*}{$\begin{array}{l}\text { General attitude } \\
\text { immigrants } \\
(1-10)\end{array}$} & \multirow[t]{2}{*}{ Immigrant status } & \multirow[t]{2}{*}{$\begin{array}{l}\text { FAS } \\
(0-9)\end{array}$} & \multicolumn{2}{|c|}{$\begin{array}{l}\text { Life satisfaction } \\
(0-10)\end{array}$} & \multicolumn{2}{|c|}{$\begin{array}{l}\text { Psychosomatic } \\
(1-5)\end{array}$} & \multicolumn{2}{|c|}{$\begin{array}{l}\text { Physical fighting } \\
(1-5)\end{array}$} & \multicolumn{2}{|c|}{$\begin{array}{l}\text { Bullying } \\
(1-5)\end{array}$} \\
\hline & & & & & & & $+\mathrm{FAS}$ & & $+\mathrm{FAS}$ & & + FAS & & + FAS \\
\hline \multirow[t]{3}{*}{ Total } & & & & Natives $(\mathrm{n}=42,941)$ & $6.38^{\mathrm{a}}$ & $7.76^{\mathrm{a}}$ & $7.74^{\mathrm{a}}$ & $1.96^{\mathrm{a}}$ & 1.97 & $1.67^{\mathrm{a}}$ & $1.67^{\mathrm{a}}$ & $1.33^{\mathrm{a}}$ & $1.33^{\mathrm{a}}$ \\
\hline & & & & First $(\mathrm{n}=4,053)$ & $5.73^{\mathrm{b}}$ & $7.59^{\mathrm{b}}$ & $7.68^{\mathrm{ab}}$ & $2.00^{\mathrm{b}}$ & 1.99 & $1.84^{\mathrm{b}}$ & $1.83^{\mathrm{b}}$ & $1.41^{\mathrm{b}}$ & $1.40^{\mathrm{b}}$ \\
\hline & & & & Second $(\mathrm{n}=6,224)$ & $5.90^{c}$ & $7.53^{b}$ & $7.59^{\mathrm{b}}$ & $1.98^{\mathrm{ab}}$ & 1.97 & $1.79^{\mathrm{b}}$ & $1.78^{\mathrm{b}}$ & $1.42^{\mathrm{b}}$ & $1.42^{\mathrm{b}}$ \\
\hline \multirow[t]{3}{*}{ Denmark } & Turkey & 53 & 5.74 & Natives $(\mathrm{n}=3,391)$ & $6.77^{\mathrm{a}}$ & 7.54 & 7.53 & 1.83 & 1.81 & $1.57^{\mathrm{a}}$ & $1.58^{\mathrm{a}}$ & $1.24^{\mathrm{a}}$ & $1.24^{\mathrm{a}}$ \\
\hline & Iraq & & & First $(n=189)$ & $6.10^{\mathrm{b}}$ & 7.49 & 7.54 & 1.87 & 1.87 & $1.93^{\mathrm{b}}$ & $1.91^{\mathrm{b}}$ & $1.44^{\mathrm{b}}$ & $1.42^{\mathrm{b}}$ \\
\hline & Vietnam & & & Second $(n=593)$ & $6.02^{\mathrm{b}}$ & 7.60 & 7.66 & 1.87 & 1.86 & $1.96^{\mathrm{b}}$ & $1.95^{\mathrm{b}}$ & $1.49^{\mathrm{b}}$ & $1.48^{\mathrm{b}}$ \\
\hline \multirow[t]{3}{*}{ Germany } & Poland & 57 & 4.37 & Natives $(\mathrm{n}=3,654)$ & $6.39^{\mathrm{a}}$ & $7.47^{\mathrm{a}}$ & 7.45 & $1.83^{\mathrm{a}}$ & $1.83^{\mathrm{a}}$ & $1.33^{\mathrm{a}}$ & $1.33^{\mathrm{a}}$ & 1.53 & $1.53^{\mathrm{a}}$ \\
\hline & Turkey & & & First $(n=191)$ & $5.51^{\mathrm{b}}$ & $7.17^{\mathrm{ab}}$ & 7.31 & $1.96^{\mathrm{b}}$ & $1.96^{\mathrm{b}}$ & $1.67^{\mathrm{b}}$ & $1.65^{\mathrm{b}}$ & 1.69 & $1.72^{\mathrm{b}}$ \\
\hline & Russia & & & Second $(n=991)$ & $5.58^{\mathrm{b}}$ & $7.28^{\mathrm{b}}$ & 7.34 & $1.91^{\mathrm{b}}$ & $1.91^{\mathrm{b}}$ & $1.63^{\mathrm{b}}$ & $1.63^{\mathrm{b}}$ & 1.60 & $1.62^{\mathrm{b}}$ \\
\hline \multirow[t]{3}{*}{ Greece } & Albania & 49 & 4.37 & Natives $(\mathrm{n}=4,053)$ & $5.58^{\mathrm{a}}$ & 7.86 & 7.83 & 2.00 & 2.00 & $2.00^{\mathrm{a}}$ & $2.00^{\mathrm{a}}$ & 1.68 & 1.68 \\
\hline & Russia & & & First $(n=362)$ & $4.68^{\mathrm{b}}$ & 7.76 & 7.85 & 1.98 & 1.97 & $2.07^{\mathrm{ab}}$ & $2.09^{\mathrm{ab}}$ & 1.67 & 1.69 \\
\hline & Georgia & & & Second $(n=364)$ & $5.29^{c}$ & 7.75 & 7.77 & 2.05 & 2.05 & $2.27^{\mathrm{b}}$ & $2.28^{\mathrm{b}}$ & 1.70 & 1.71 \\
\hline \multirow[t]{3}{*}{ Iceland } & Poland & - & 5.88 & Natives $(\mathrm{n}=9,161)$ & $7.19^{\mathrm{a}}$ & $8.01^{\mathrm{a}}$ & $8.00^{\mathrm{a}}$ & $2.08^{\mathrm{a}}$ & 2.08 & $1.63^{\mathrm{a}}$ & $1.63^{\mathrm{a}}$ & $1.21^{\mathrm{a}}$ & $1.21^{\mathrm{a}}$ \\
\hline & Denmark & & & First $(n=936)$ & $6.70^{\mathrm{b}}$ & $7.88^{\mathrm{ab}}$ & $7.99^{\mathrm{a}}$ & $2.07^{\mathrm{ab}}$ & 2.05 & $1.74^{\mathrm{b}}$ & $1.73^{\mathrm{b}}$ & $1.33^{\mathrm{b}}$ & $1.30^{\mathrm{b}}$ \\
\hline & Philippines & & & Second $(n=796)$ & $6.78^{\mathrm{b}}$ & $7.68^{\mathrm{b}}$ & $7.78^{\mathrm{b}}$ & $2.16^{\mathrm{b}}$ & 2.13 & $1.73^{\mathrm{ab}}$ & $1.72^{\mathrm{ab}}$ & $1.25^{\mathrm{a}}$ & $1.25^{\mathrm{ab}}$ \\
\hline \multirow[t]{3}{*}{ Ireland } & England & 49 & 4.56 & Natives $(\mathrm{n}=3,199)$ & $5.65^{\mathrm{a}}$ & $7.65^{\mathrm{a}}$ & $7.67^{\mathrm{a}}$ & $1.90^{\mathrm{a}}$ & $1.90^{\mathrm{a}}$ & $1.69^{\mathrm{a}}$ & $1.68^{\mathrm{a}}$ & 1.24 & 1.24 \\
\hline & Poland & & & First $(\mathrm{n}=725)$ & $5.67^{\mathrm{ab}}$ & $7.40^{\mathrm{b}}$ & $7.41^{\mathrm{b}}$ & $2.01^{\mathrm{b}}$ & $2.00^{\mathrm{b}}$ & $1.82^{\mathrm{b}}$ & $1.82^{\mathrm{b}}$ & 1.29 & 1.29 \\
\hline & Nigeria & & & Second $(n=651)$ & $5.90^{\mathrm{b}}$ & $7.50^{\mathrm{ab}}$ & $7.53^{\mathrm{ab}}$ & $1.99^{\mathrm{b}}$ & $2.00^{\mathrm{b}}$ & $1.73^{\mathrm{ab}}$ & $1.72^{\mathrm{ab}}$ & 1.25 & 1.23 \\
\hline \multirow[t]{3}{*}{ Italy } & Romania & 60 & 5.29 & Natives $(\mathrm{n}=3,916)$ & $5.76^{\mathrm{a}}$ & $7.57^{\mathrm{a}}$ & 7.56 & 2.24 & 2.24 & $1.70^{\mathrm{a}}$ & $1.70^{\mathrm{a}}$ & 1.25 & $1.25^{\mathrm{a}}$ \\
\hline & Albania & & & First $(n=281)$ & $4.96^{\mathrm{b}}$ & $7.18^{\mathrm{b}}$ & 7.29 & 2.25 & 2.24 & $1.87^{\mathrm{ab}}$ & $1.88^{\mathrm{b}}$ & 1.34 & $1.35^{\mathrm{b}}$ \\
\hline & Morocco & & & Second $(n=404)$ & $5.57^{\mathrm{a}}$ & $7.38^{\mathrm{ab}}$ & 7.41 & 2.31 & 2.31 & $1.86^{\mathrm{b}}$ & $1.86^{\mathrm{b}}$ & 1.28 & $1.28^{\mathrm{ab}}$ \\
\hline \multirow[t]{3}{*}{ Netherlands } & Morocco & 68 & 5.37 & Natives $(\mathrm{n}=3,567)$ & $6.78^{\mathrm{a}}$ & 7.99 & $7.97^{\mathrm{a}}$ & 1.77 & 1.77 & $1.57^{\mathrm{a}}$ & $1.57^{\mathrm{a}}$ & $1.37^{\mathrm{a}}$ & $1.37^{\mathrm{a}}$ \\
\hline & Turkey & & & First $(n=179)$ & $6.01^{\mathrm{b}}$ & 8.21 & $8.25^{\mathrm{b}}$ & 1.82 & 1.78 & $1.81^{\mathrm{b}}$ & $1.80^{\mathrm{b}}$ & $1.59^{\mathrm{b}}$ & $1.59^{\mathrm{b}}$ \\
\hline & Surinam & & & Second $(n=696)$ & $5.83^{\mathrm{b}}$ & 7.99 & $8.04^{\mathrm{ab}}$ & 1.78 & 1.78 & $1.77^{\mathrm{b}}$ & $1.77^{\mathrm{b}}$ & $1.53^{\mathrm{b}}$ & $1.54^{\mathrm{b}}$ \\
\hline \multirow[t]{3}{*}{ Spain } & Ecuador & 63 & 5.51 & Natives $(n=4,186)$ & $6.20^{\mathrm{a}}$ & $8.01^{\mathrm{a}}$ & 7.99 & 1.87 & 1.87 & $1.90^{\mathrm{a}}$ & $1.90^{\mathrm{a}}$ & 1.31 & 1.31 \\
\hline & Morocco & & & First $(n=508)$ & $5.33^{\mathrm{b}}$ & $7.69^{\mathrm{b}}$ & 7.81 & 1.90 & 1.86 & $2.12^{\mathrm{b}}$ & $2.11^{\mathrm{b}}$ & 1.33 & 1.34 \\
\hline & Colombia & & & Second $(n=305)$ & $6.01^{\mathrm{a}}$ & $7.87^{\mathrm{ab}}$ & 7.89 & 1.91 & 1.91 & $2.02^{\mathrm{ab}}$ & $2.02^{\mathrm{ab}}$ & 1.39 & 1.39 \\
\hline \multirow[t]{3}{*}{ Wales $^{\mathrm{f}}$} & Ireland & - & - & Natives $(\mathrm{n}=4,318)$ & $6.06^{\mathrm{a}}$ & 7.40 & 7.36 & 1.90 & 1.92 & 1.68 & 1.66 & $1.22^{\mathrm{a}}$ & 1.22 \\
\hline & Bangladesh & & & First $(n=212)$ & $5.63^{\mathrm{b}}$ & 7.08 & 7.15 & 1.95 & 1.95 & 1.62 & 1.59 & $1.33^{\mathrm{b}}$ & 1.32 \\
\hline & India & & & Second $(n=341)$ & $5.92^{\mathrm{ab}}$ & 7.38 & 7.31 & 1.95 & 1.96 & 1.66 & 1.63 & $1.26^{\mathrm{ab}}$ & 1.25 \\
\hline \multirow[t]{3}{*}{ USA } & Mexico & 62 & - & Natives $(\mathrm{n}=3,496)$ & $6.30^{\mathrm{a}}$ & $7.68^{\mathrm{a}}$ & $7.65^{\mathrm{a}}$ & $2.05^{\mathrm{a}}$ & $2.05^{\mathrm{a}}$ & 1.66 & 1.66 & 1.40 & 1.41 \\
\hline & Philippines & & & First $(n=470)$ & $5.46^{\mathrm{b}}$ & $7.47^{\mathrm{ab}}$ & $7.56^{\mathrm{ab}}$ & $1.98^{\mathrm{ab}}$ & $1.96^{\mathrm{ab}}$ & 1.78 & 1.77 & 1.45 & 1.45 \\
\hline & El Salvador & & & Second $(n=1,083)$ & $5.83^{\mathrm{c}}$ & $7.29^{\mathrm{b}}$ & $7.33^{\mathrm{b}}$ & $1.96^{\mathrm{b}}$ & $1.95^{\mathrm{b}}$ & 1.71 & 1.70 & 1.41 & 1.41 \\
\hline
\end{tabular}

Estimated marginal means are presented, controlling (1) for age and gender and (2) for age, gender, and family affluence.

Different superscripts (a, b, and, c) refer to differences between natives and first- and second-generation immigrants.

FAS = Family Affluence Scale; MIPEX = Migrant Integration Policy Index.

MIPEX 2010 assesses integration policies by 148 policy indicators to identify whether residents are guaranteed equal rights, responsibilities, and opportunities. Higher scores indicate more equal policies.

e Aggregated indicator on attitudes against immigrants, with higher scores indicative of more positive attitudes. Information is obtained from the European Values Study 2008 , a cross-national survey on values of adults in Europe.

${ }^{\mathrm{f}}$ Immigrant status refers to being born outside the United Kingdom. 
immigrants in the participating countries, with relatively unfavorable scores in Greece and Ireland.

\section{Measures}

Immigrant status. Adolescents were asked whether they and each of their mother and father were born in the receiving country or abroad. Adolescents were considered a firstgeneration immigrant, if they were born abroad. Adolescents were considered a second-generation immigrant if at least one of their parents was born abroad and they themselves were born in the receiving country. Former research indicated that 11 -year-old children provide valid responses to these questions, by showing that the amount of agreement between the answers of the children and their parents is almost 100\% [31]. The ethnic background of the adolescent was defined as the country of birth of the mother. In case the country of birth of the mother was the receiving country or a missing value, the country of birth of the father was used as an indicator of the ethnic background of the adolescent.

Life satisfaction was assessed by means of a visual analogue scale. This scale has 11 steps ranging from the best possible life on the top of a ladder (10) to the worst possible life at the bottom (0). Respondents were asked to indicate the step of the ladder at which they would place their lives at present.

Psychosomatic complaints were assessed by an eight-item symptom checklist. Participants were asked how often they had experienced the following symptoms in the past 6 months: headache, stomach ache, back ache, feeling low, irritability or bad temper, feeling nervous, difficulties in getting to sleep, and feeling dizzy. Answering categories were: "rarely or never" (1); "about every month" (2); "about every week" (3); "more than once a week" (4); and "about every day" (5). Scale scores were calculated by summing the score of all items and subsequently dividing this score through eight. Participants with one missing score on this scale were given the mean score on this item before calculating the sum score.

Physical fighting was assessed by asking how many times adolescents had been involved in a physical fight during the past 12 months ["never" (1); “once" (2); "2 times" (3); "3 times" (4); and "4 times or more" (5)]. To measure bullying, adolescents were asked how often they had taken part in bullying (an) other pupil(s) at school in the past couple of months, with five answering categories "I have not bullied another pupil in the past couple of months" (1); "it has happened once or twice" (2); "two or three times a month" (3); "about once a week" (4); and "several times a week" (5). This question was preceded by a definition of bullying [32].

Socio demographic variables. The Family Affluence Scale (FAS) is an indicator of young people's socioeconomic status and comprises four items on material assets in the family. If participants had a missing score on one FAS item, they were given the mean score on this item before calculating the total scale score. A former study showed consistent relations between the FAS and other indicators of socioeconomic status [33].

Missing values on age (1.5\%) were replaced by the mean value of the total sample (13.537). Listwise deletion procedure was used to exclude cases with missing values on the other variables. Overall, the percentage of missing values was low (gender, $0 \%$; life satisfaction, $2.2 \%$; bullying, $3.3 \%$; psychosomatic symptoms, 2.3\%; family affluence, 3.3\%; physical fighting, 5.2\%). For adolescents with missing information on one of their parents' country of birth, the country of birth of the other parent was used to establish whether the adolescent could be considered a second-generation immigrant. Adolescents with missing values on their own country of birth and adolescents who were born in the receiving country and had missing values on the country of birth of both of their parents were excluded from the analyses (5.9\% of the adolescents).

\section{Statistical procedure}

All analyses were conducted using SPSS 20.0 (IBM Corp., Armonk, NY). First, possible differences in the ethnic background between first- and second-generation immigrant adolescents were tested by a Pearson's chi-square test. Second, differences in adolescent emotional and behavioral problems and family affluence between natives, first-generation immigrants, and second-generation immigrants in the participating countries and in the total population were explored by means of general linear models including gender and age as covariates. For emotional and behavioral problems, family affluence was also included as a covariate. Differences between the three groups were assessed by the Bonferroni tests.

Third, multilevel analyses were conducted to investigate the relationship between immigrant status and emotional and behavioral problems. Three separate models were run. In Model 1 , the relationship between immigrant status and adolescent emotional and behavioral problems was assessed when controlling for gender and age with native adolescents as the reference group. In Model 2, family affluence was added to the model. To establish whether differences in emotional and behavioral problems between first- and second-generation immigrant adolescents occurred, Models 1-2 were rerun with first-generation immigrant adolescents as the reference group. In Model 3, interactions between immigrant status and gender were included. In case of significant gender $\times$ immigrant status interactions, Model 2 was run separately for boys and girls. As a sensitivity analysis, we reran the models in a three-level multilevel analysis, adding schools as an extra-analytic level to account for the clustering of participants within schools. These models did not lead to different conclusions, indicating that the results cannot be explained by differences in school composition. Finally, random slope effects across countries for the comparison between first- or second-generation immigrants and natives were conducted without (Model 1) and with (Model 2) controlling for family affluence. Significant random slope effects $(p<.05)$ indicated that the effects of immigrant status were different across countries.

\section{Results}

Table 2 provides the ethnic background of the three largest immigrant groups in the participating countries and indicates that the ethnic background of the adolescents varies with the immigrant generation. As reported in Table 1, for all countries (except Ireland), immigrant adolescents showed a lower family affluence than their native peers, and in four countries, differences were only found or more pronounced for first-generation immigrant compared with second-generation immigrant adolescents. In more than $50 \%$ of the comparisons between natives and immigrants not including family affluence, more emotional and behavioral problems were found in first- and/or 
Table 2

Ethnic background of the three largest immigrant groups per country by immigrant status

\begin{tabular}{lcr}
\hline & First generation, n (\%) & Second generation, n (\%) \\
\hline Albania & $208(61)$ & $134(39)$ \\
Bangladesh & $6(12)$ & $43(88)$ \\
Colombia & $60(90)$ & $7(10)$ \\
Denmark & $29(19)$ & $124(81)$ \\
Ecuador & $75(94)$ & $5(6)$ \\
England & $180(28)$ & $453(72)$ \\
El Salvador & $7(14)$ & $43(86)$ \\
Georgia & $23(56)$ & $18(44)$ \\
Iraq & $20(63)$ & $12(38)$ \\
India & $16(55)$ & $13(45)$ \\
Ireland & $4(7)$ & $51(93)$ \\
Mexico & $120(23)$ & $413(77)$ \\
Morocco & $68(26)$ & $192(74)$ \\
Nigeria & $28(88)$ & $4(12)$ \\
Philippines & $55(36)$ & $99(64)$ \\
Poland & $198(57)$ & $152(43)$ \\
Romania & $47(84)$ & $9(16)$ \\
Russia & $57(30)$ & $133(70)$ \\
Surinam & $9(9)$ & $94(91)$ \\
Turkey & $25(5)$ & $488(95)$ \\
Vietnam & $2(6)$ & $30(94)$ \\
\hline & &
\end{tabular}

$\chi=884, d f=20, p<.01$

second-generation immigrant than in native adolescents. In contrast, only one association was indicative of fewer problems in immigrants (in the United States, natives reported higher psychosomatic symptoms than second-generation immigrants). With one exception (higher levels of bullying in first-generation immigrants compared with second-generation immigrants in Iceland), no differences in outcome variables were revealed between first- and second-generation immigrants. When taking into account family affluence, differences remained largely similar. Most notably, for some countries, differences in life satisfaction or psychosomatic symptoms between first- or second-generation immigrant and native adolescents disappeared (Germany, Iceland, Italy, Spain) or reversed effects were found (the Netherlands).

Multilevel linear regression analyses showed lower levels of life satisfaction for first- and second-generation immigrant than native adolescents (Model 1, Table 3). Although the effect of immigrant status on life satisfaction reduced considerably after controlling for family affluence, lower levels of life satisfaction were still found for first- and second-generation immigrants than for natives (Model 2). Differences between immigrants and natives in life satisfaction were statistically significant, but fairly modest substantively (around .1 on an 11-point scale). Comparing first- and second-generation immigrants (not reported in Table 3), no differences were found between the two groups. Effects of immigration were similar for boys and girls (Model 3). The random slopes (across countries) for the comparison of first- and second-generation immigrant with native adolescents (before and after controlling for family affluence) were not significant, suggesting that the effect of immigrant status on life satisfaction did not vary significantly across countries (not reported in Table 3).

Next, multilevel analyses revealed higher levels of psychosomatic symptoms for second-generation immigrants than natives (Table 4, Model 1). When controlling for family affluence, this difference remained significant, although the effect was small in substantive terms (.027 on a five-point scale; Table 4,
Table 3

Results of multilevel linear regression of life satisfaction on immigrant status, gender, and family affluence

\begin{tabular}{|c|c|c|c|c|c|c|}
\hline & \multicolumn{2}{|l|}{ Model 1} & \multicolumn{2}{|l|}{ Model 2} & \multicolumn{2}{|l|}{ Model 3} \\
\hline & B & SE & B & SE & B & SE \\
\hline Constant & $10.736^{* *}$ & .102 & $9.867^{* *}$ & .103 & $9.874^{* *}$ & .104 \\
\hline Gender ( 1 = female $)$ & $-.188^{* *}$ & .016 & $-.177^{* *}$ & .016 & $-.181^{* *}$ & .017 \\
\hline Age & $-.201^{* *}$ & .005 & $-.202^{* *}$ & .005 & $-.202^{* *}$ & .005 \\
\hline \multicolumn{7}{|l|}{ Immigrant status } \\
\hline Native (ref.) & - & - & - & - & - & - \\
\hline First generation & $-.185^{* *}$ & .031 & $-.100^{* *}$ & .030 & .018 & .098 \\
\hline Second generation & $-.173^{* *}$ & .025 & $-.110^{* *}$ & .025 & $-.238^{* *}$ & .078 \\
\hline Family Affluence Scale & & & $.138^{* *}$ & .005 & $.138^{* *}$ & .005 \\
\hline $\begin{array}{l}\text { Gender } \times \text { first } \\
\text { generation }\end{array}$ & & & & & -.079 & .060 \\
\hline $\begin{array}{l}\text { Gender } \times \text { second } \\
\text { generation }\end{array}$ & & & & & .084 & .049 \\
\hline $\begin{array}{l}\text { Level } 1 \text { variance } \\
\text { (individuals) }\end{array}$ & $3.189^{* *}$ & .020 & $3.136^{* *}$ & .020 & $3.136^{* *}$ & .020 \\
\hline $\begin{array}{l}\text { Level } 2 \text { variance } \\
\text { (countries) }\end{array}$ & $.051^{*}$ & .023 & $.047^{*}$ & .021 & $.047^{*}$ & .021 \\
\hline-2 Log likelihood & $203,142.1$ & & $202,282.8$ & & $202,277.6$ & \\
\hline
\end{tabular}

$\mathrm{N}_{1}=50,803 ; \mathrm{N}_{2}=10$

$\mathrm{SE}=$ standard error.

${ }^{*} p<.05{ }^{* *} p<.01$ (two-tailed)

Model 2). Results did not show differences in psychosomatic symptoms between first-and second-generation immigrants (not shown in the Table). Interactions between gender and immigrant status were found for first-generation immigrants (Table 4, Model 3). First-generation immigrant boys reported less psychosomatic complaints than native boys $(B=-.021, p<.01)$, whereas no differences in psychosomatic symptoms were found between first-generation immigrant and native girls. None of the random slopes (across countries) for the comparison of first- and second-generation immigrant with native adolescents (before and after controlling for family affluence) were significant (not reported in Table 4).

Multilevel analyses of immigrant status on physical fighting and bullying are reported in Tables 5 and 6. Both the tables show

Table 4

Results of multilevel linear regression of psychosomatic problems on immigrant status, gender, and family affluence

\begin{tabular}{|c|c|c|c|c|c|c|}
\hline & \multicolumn{2}{|l|}{ Model 1} & \multicolumn{2}{|l|}{ Model 2} & \multicolumn{2}{|l|}{ Model 3} \\
\hline & B & SE & B & SE & B & SE \\
\hline Constant & $.588^{* *}$ & .052 & $.711^{* *}$ & .053 & $.710^{* *}$ & .053 \\
\hline Gender ( 1 = female) & $.273^{* *}$ & .007 & $.271^{* *}$ & .007 & $.272^{* *}$ & .007 \\
\hline Age & $.070^{* *}$ & .002 & $.070^{* *}$ & .002 & $.070^{* *}$ & .002 \\
\hline \multicolumn{7}{|l|}{ Immigrant status } \\
\hline Native (ref.) & - & - & - & - & - & - \\
\hline First generation & .020 & .013 & .008 & .013 & -.074 & .041 \\
\hline Second generation & $.036^{* *}$ & .011 & $.027^{*}$ & .011 & $.084^{*}$ & .034 \\
\hline Family Affluence Scale & & & $-.019^{* *}$ & .002 & $-.019^{* *}$ & .002 \\
\hline $\begin{array}{l}\text { Gender } \times \text { first } \\
\text { generation }\end{array}$ & & & & & $.054^{*}$ & .026 \\
\hline $\begin{array}{l}\text { Gender } \times \text { second } \\
\text { generation }\end{array}$ & & & & & -.037 & .021 \\
\hline $\begin{array}{l}\text { Level } 1 \text { variance } \\
\text { (individuals) }\end{array}$ & $.577^{* *}$ & .004 & $.576^{* *}$ & .004 & $.576^{* *}$ & .004 \\
\hline $\begin{array}{l}\text { Level } 2 \text { variance } \\
\text { (countries) }\end{array}$ & $.018^{*}$ & .008 & $.018^{*}$ & .008 & $.017^{*}$ & .008 \\
\hline-2 Log likelihood & $116,491.3$ & & $116,397.0$ & & $116,388.7$ & \\
\hline
\end{tabular}

$\mathrm{N}_{1}=50,874 ; \mathrm{N}_{2}=10$

$\mathrm{SE}=$ standard error

${ }^{*} p<.05 ;{ }^{* *} p<.01$ (two-tailed) 
Table 5

Results of multilevel linear regression of physical fighting on immigrant status, gender, and family affluence

\begin{tabular}{|c|c|c|c|c|c|c|}
\hline & \multicolumn{2}{|l|}{ Model 1} & \multicolumn{2}{|l|}{ Model 2} & \multicolumn{2}{|l|}{ Model 3} \\
\hline & B & SE & B & SE & B & SE \\
\hline Constant & $3.112^{* *}$ & .069 & $3.147^{* *}$ & .071 & $3.127^{* *}$ & .071 \\
\hline Gender ( 1 = female) & $-.618^{* *}$ & .010 & $-.620^{* *}$ & .010 & $-.607^{* *}$ & .011 \\
\hline Age & $-.038^{* *}$ & .003 & $-.038^{* *}$ & .003 & $-.038^{* *}$ & .003 \\
\hline \multicolumn{7}{|l|}{ Immigrant status } \\
\hline Native (ref.) & - & - & - & - & - & - \\
\hline First generation & $.156^{* *}$ & .019 & $.153^{* *}$ & .020 & $.319^{* *}$ & .061 \\
\hline Second generation & $.163^{* *}$ & .016 & $.160^{* *}$ & .016 & $.226^{* *}$ & .050 \\
\hline Family Affluence Scale & & & -.005 & .003 & -.005 & .003 \\
\hline $\begin{array}{l}\text { Gender } \times \text { first } \\
\text { generation }\end{array}$ & & & & & $-.110^{* *}$ & .039 \\
\hline $\begin{array}{l}\text { Gender } \times \text { second } \\
\text { generation }\end{array}$ & & & & & -.044 & .031 \\
\hline $\begin{array}{l}\text { Level } 1 \text { variance } \\
\text { (individuals) }\end{array}$ & $1.241^{* *}$ & .008 & $1.241^{* *}$ & .008 & $1.240^{* *}$ & .008 \\
\hline $\begin{array}{l}\text { Level } 2 \text { variance } \\
\text { (countries) }\end{array}$ & $.027^{*}$ & .012 & $.027^{*}$ & .012 & $.027^{*}$ & .012 \\
\hline-2 Log Likelihood & $150,925.0$ & & $150,922.2$ & & $150,912.8$ & \\
\hline
\end{tabular}

$\mathrm{N}_{1}=49,412 ; \mathrm{N}_{2}=10$

$\mathrm{SE}=$ standard error.

${ }^{*} p<.05 ;{ }^{* *} p<.01$ (two-tailed).

higher levels of physical fighting and bullying for the first- and second-generation immigrant than native adolescents with and without controlling for family affluence (see Models 1 and 2). The effect of immigrant status on physical fighting was clearly more substantive than the effect on bullying (for fighting, the effects are .153 and .160 on a five-point scale, whereas for bullying, the effects are .091 and .067 on a five-point scale). No differences between first- and second-generation immigrants on either physical fighting or bullying were revealed (not reported in the Tables). For the comparison between first-generation immigrants and natives on physical fighting, an interaction with gender was found. First-generation immigrant boys and girls showed higher levels of physical fighting than their native peers, but differences were more pronounced for boys $(B=.114, p<.01)$

\section{Table 6}

Results of multilevel linear regression of bullying on immigrant status, gender, and family affluence

\begin{tabular}{|c|c|c|c|c|c|c|}
\hline & \multicolumn{2}{|l|}{ Model 1} & \multicolumn{2}{|l|}{ Model 2} & \multicolumn{2}{|l|}{ Model 3} \\
\hline & B & SE & B & SE & B & SE \\
\hline Constant & $1.256^{* *}$ & .055 & $1.249^{* *}$ & .057 & $1.240^{* *}$ & .057 \\
\hline Gender ( 1 = female $)$ & $-.218^{* *}$ & .007 & $-.218^{* *}$ & .007 & $-.212^{* *}$ & .007 \\
\hline Age & $.031^{* *}$ & .002 & $.031^{* *}$ & .002 & $.031^{* *}$ & .002 \\
\hline \multicolumn{7}{|l|}{ Immigrant status } \\
\hline Native (ref.) & - & - & - & - & - & - \\
\hline First generation & $.090^{* *}$ & .013 & $.091^{* *}$ & .013 & $.146^{* *}$ & .040 \\
\hline Second generation & $.067^{* *}$ & .010 & $.067^{* *}$ & .010 & $.112^{* *}$ & .033 \\
\hline Family Affluence Scale & & & .001 & .002 & .001 & .002 \\
\hline $\begin{array}{l}\text { Gender } \times \text { first } \\
\text { generation }\end{array}$ & & & & & -.038 & .025 \\
\hline $\begin{array}{l}\text { Gender } \times \text { second } \\
\text { generation }\end{array}$ & & & & & -.029 & .020 \\
\hline $\begin{array}{l}\text { Level } 1 \text { variance } \\
\text { (individuals) }\end{array}$ & $.540^{* *}$ & .003 & $.540^{* *}$ & .003 & $.540^{* *}$ & .003 \\
\hline $\begin{array}{l}\text { Level } 2 \text { variance } \\
\text { (countries) }\end{array}$ & $.022^{*}$ & .010 & $.022^{*}$ & .010 & $.022^{*}$ & .010 \\
\hline-2 Log Likelihood & $112,412.4$ & & $121,412.1$ & & $112,408.4$ & \\
\hline
\end{tabular}

$\mathrm{N}_{1}=50,575 ; \mathrm{N}_{2}=10$.

$\mathrm{SE}=$ standard error.

${ }^{*} p<.05 ;{ }^{* *} p<.01$ (two-tailed). than for girls $(B=.066, p<.01)$. None of the random slopes (across countries) for the comparison of first- and secondgeneration immigrants with native adolescents (before and after controlling for family affluence) were significant (not reported in Tables 5 and 6).

\section{Discussion}

This internationally comparative study showed that both first- and second-generation immigrant adolescents report lower levels of life satisfaction and higher levels of physical fighting and bullying than their native peers. The effect of immigrant status on physical fighting stood out as particularly strong, whereas the effect on psychosomatic symptoms was significant but modest for second-generation immigrants and absent for first-generation immigrants. For life satisfaction, immigration effects became less pronounced when controlling for family affluence. In addition, first- and second-generation immigrant adolescents reported equally high levels of these problems, and effects of immigration did not vary significantly with the receiving country. Gender differences in the impact of immigration were found for only two of eight comparisons. Firstgeneration immigrant girls reported as many psychosomatic symptoms as their native peers, whereas first-generation immigrant boys reported less psychosomatic symptoms than their native peers. In contrast, both second-generation immigrant boys and girls reported higher levels of physical fighting than their native peers, but differences were more pronounced for boys than for girls.

Overall, the results are largely in line with a risk perspective on immigration. Findings suggest that being a first- or secondgeneration immigrant adolescent brings about stress which subsequently leads to relatively high levels of emotional and behavioral problems. Additionally, no differences between the two immigrant groups were found, which also seems inconsistent with the immigrant paradox perspective. However, the immigrant paradox perspective cannot be discarded entirely as the general linear models did not show an impact of immigration in all countries, effect sizes varied considerably with the specific outcome and effects decreased when controlling for family affluence.

No indications were found for receiving country-level differences in the impact of immigration. This result might be perceived as remarkable because there are indications for differences in migration policies and attitudes against immigrants between the 10 participating countries. These differences in immigrant attitudes and immigrant policies may also be associated with differences in prejudice and discrimination [34]. Still, effects of migration on adolescent emotional and behavioral problems were comparable between countries.

Gender differences in the impact of immigration were only found for psychosomatic symptoms and physical fighting. In line with previous research $[28,29]$, immigrant boys showed especially high levels of physical fighting in contrast to their native peers, but this was only the case for second-generation immigrants. Inconsistent with several Norwegian studies [24,26,27], first-generation immigrant girls showed as many psychosomatic symptoms as native girls, whereas immigrant boys showed fewer symptoms than native boys. Findings from this study may reflect the complex interplay between immigrant generation, gender, and different types of adolescent emotional and behavioral problems. 
This study is one of the first to investigate receiving countrylevel differences in the impact of immigration on adolescent emotional and behavioral problems, taking into account gender and immigrant generation as moderators of this impact. As such, it contributes to the expanding research in this field. However, some limitations of our study should be considered. First of all, because of sample sizes, we were unable to distinguish between immigrants originating from different ethnic backgrounds, although we could expect that the effects of immigration may vary with the ethnic background of the adolescent [1,3]. Related to this, we cannot rule out that the absence of differences between first- and second-generation immigrant adolescents is partly due to differences in their ethnic backgrounds. Second, to gain insight into the importance of immigrant generation, a distinction was made between adolescents who were born in the country of origin (first-generation immigrants) and adolescents who were born in the receiving country (second-generation immigrants). However, no information was available on the length of residence in the receiving country of first-generation immigrant adolescents, making it impossible to determine whether most of these adolescents were socialized within the receiving country or the country of origin. Third, our outcomes have been used in ample former studies showing associations with relevant constructs for adolescents throughout Europe [35-38], and there are some indications that self-reported emotional and behavioral problems can be validly assessed throughout immigrant and nonimmigrant samples $[39,40]$. However, still differences between groups might be due to differences in the validity of the instruments for immigrant and native populations.

Notwithstanding the limitations, our study indicates that the first- and second-generation immigrant adolescents run an increased risk of emotional and behavioral problems as compared with their native peers, and that this risk does not significantly differ between receiving countries. Results imply that both on a national and international level, policy makers should (continue to) devise strategies to improve the lives of immigrants. For instance, school intervention programs and awareness among teachers are needed to identify young immigrants at risk of these problems. To develop these strategies, scientific scholars need to fuel policy makers by identifying those factors that can explain the differences in emotional and behavioral problems between immigrant and native adolescents.

\section{Acknowledgments}

The first draft has been written by the first author in collaboration with all coauthors. No prior publications have been written using overlapping information, and this article is not under consideration elsewhere. However, a poster using this data has been presented at the Society for Research on Adolescence in 2014.

\section{References}

[1] Stevens GW, Vollebergh WA. Mental health in migrant children. J Child Psychol Psychiatry 2008;49:276-94.

[2] Brenick A, Silbereisen RK. Leaving (for) home. Understanding return migration from the diaspora. Eur Psychol 2012;17:85-92.

[3] Stoessel K, Titzmann PF, Silbereisen RK. Young diaspora immigrants' attitude and behavior toward the host culture. The role of cultural identification. Eur Psychol 2012;17:143-57.

[4] Molcho M, Cristini F, Nic Gabhainn S, et al. Health and well-being among child immigrants in Europe. Eurohealth 2010;16:20-3.
[5] Sam DL, Vedder P, Liebkind K, et al. Immigration, acculturation and the paradox of adaptation in Europe. Eur J Dev Psychol 2008;5:138-58.

[6] Sam DL, Virta E. Intergenerational value discrepancies in immigrant and host-national families and their impact on psychological adaption. J Adolesc 2003;26:213-31.

[7] Virta E, Sam DL, Westin C. Adolescents with Turkish background in Norway and Sweden: A comparative study of their psychological adaptation. Scand J Psychol 2004;45:15-25.

[8] Guarnaccia PJ, Lopez S. The mental health and adjustment of immigrant and refugee children. Child Adolesc Psychiatr Clin N Am 1998;7:537-53.

[9] Le TN, Stockdale GD. Acculturative dissonance, ethnic identity, and youth violence. Cultur Divers Ethnic Minor Psychol 2008;14:1-9.

[10] Noh S, Kaspar V. Perceived discrimination and depression: Moderating effects of coping, acculturation, and ethnic support. Am J Public Health 2003;93:232-8

[11] Pascoe EA, Smart Richman LS. Perceived discrimination and health: A meta-analytic review. Psychol Bull 2009;135:531-54.

[12] Fuligni AJ. The intersection of aspirations and resources in the development of children from immigrant families. In: Garcia Coll C, Kerivan Marks A, eds. The Immigrant Paradox in Children and Adolescents: Is Becoming American a Developmental Risk? Washington, DC: American Psychological Association; 2012:61-76.

[13] Garcia Coll CG, Patton F, Kerivan Marks A, et al. Understanding the immigrant paradox in youth. In: Masten AS, Liebkind K, Hernandez DJ, eds. Realizing the Potential of Immigrant Youth. Cambridge: University Press; 2012:159-80.

[14] Portes A, Zhou M. The new second generation: Segmented assimilation and its variants. Ann Am Acad Pol Soc Sci 1993;53:74-96.

[15] Van Geel M, Vedder P. The role of family obligations and school adjustment in explaining the immigrant paradox. J Youth Adolesc 2011;40:187-96.

[16] Sam DL, Vedder P, Ward C, Horenczyk G. Psychological and socio-cultural adaptation of immigrant youth. In: Berry JW, Phinney JS, Sam DL, Vedder P, eds. Immigrant Youth in Cultural Transition: Acculturation Identity and Adaptation Across National Contexts. Mahwah, NJ: Lawrence Erlbaum Associates Inc; 2006:117-41.

[17] Pérez DM, Jennings WG, Gover AR. Specifying general strain theory: An ethnically relevant approach. Deviant Behav 2008;29:544-78.

[18] Beiser M, Hou F, Hyrnan I, Tousignant M. Poverty, family process, and the mental health of immigrant children in Canada. Am J Public Health 2002; 92:220-7.

[19] Harker K. Immigrant generation, assimilation, and adolescent psychological well-being. Soc Forces 2001;79:969-1004.

[20] Hernandez DJ, Denton NA, Macartney S, Blancard VL. Children in immigrant families: Demography, policy, and evidence for the immigrant paradox. In: Garcia Coll C, Kerivan Marks A, eds. The immigrant paradox in children and adolescents: Is becoming American a developmental risk? Washington, DC: American Psychological Association; 2012:61-76.

[21] Stewart SM, Bond MH, Abdullah AS, Ma SS. Gender, parenting, and adolescent functioning in Bangladesh. Merrill Palmer Q 2000;46: 540-63.

[22] Stevens GW, Vollebergh WA, Pels T, Crijnen AA. Problem behavior and acculturation in Moroccan immigrant adolescents in the Netherlands: Effects of gender and parent-child conflict. J Cross Cult Psychol 2007;38: 310-7.

[23] Pels T, De Haan M. Continuity and change in Moroccan socialization: A review of the literature on socialization in Morocco and among Moroccan families in the Netherlands. Utrecht: University of Utrecht/Verwey-Jonker Institute; 2003.

[24] Alves DE, Roysamb E, Oppedal B, Zachrisson HD. Emotional problems in preadolescents in Norway: The role of gender, ethnic minority status, and home- and school-related hassles. Child Adolesc Psychiatry Ment Health 2011;5:1-10.

[25] Carlerby H, Viitasara E, Knutsson A, Gillander Gådin K. Subjective health complaints among boys and girls in the Swedish HBSC study: Focusing on parental foreign background. Int J Public Health 2011;56:457-64.

[26] Fandrem H, Sam DL, Roland E. Depressive symptoms among native and immigrant adolescents in Norway: The role of gender and urbanization. Soc Indic Res 2009;92:91-109.

[27] Oppedal B, Røysamb E. Mental health, life stress and social support among young Norwegian adolescents with immigrant and host national background. Scand J Psychol 2004;45:131-44.

[28] Stevens GW, Pels TV, Bengi-Arslan L, et al. Parent, teacher and self-reported problem behavior in the Netherlands: Comparing Moroccan immigrant with Dutch and with Turkish immigrant children and adolescents. Soc Psychiatry Psychiatr Epidemiol 2003;38:576-85.

[29] Vollebergh WA, Ten Have M, Dekovic M, et al. Mental health in immigrant children in the Netherlands. Soc Psychiatry Psychiatr Epidemiol 2005;40: 489-96.

[30] Roberts C, Freeman J, Samdal O, et al. The Health Behaviour in School-aged Children (HBSC) study: Methodological developments and current tensions. Int J Public Health 2009;54:140-50. 
[31] Nordahl H, Krolner R, Pall G, et al. Measurement of ethnic background in cross-national school surveys: Agreement between students' and parents' responses. J Adolesc Health 2011;49:272-7.

[32] Olweus D. The revised Olweus Bully/Victim questionnaire. Bergen: University of Bergen; 1996.

[33] Currie C, Molcho M, Boyce W, et al. Researching health inequalities in adolescents: The development of the Health Behaviour in School-Aged Children (HBSC) Family Affluence Scale. Soc Sci Med 2009;66: $1429-36$.

[34] Garcia Coll CG, Crnic K, Lamberty G, et al. An integrative model for the study of developmental competencies in minority children. Child Dev 1996;67:1891-914.

[35] Haugland S, Wold B, Stevenson J, et al. Subjective health complaints in adolescence. A cross-national comparison of prevalence and dimensionality. Eur J Public Health 2001;11:4-10.
[36] Ravens-Sieberer U, Erhart M, Torsheim T, et al. An international scoring system for self-reported health complaints in adolescents. Eur J Public Health 2008;18:294-9.

[37] Smith-Khuri E, Iachan R, Scheidt PC, et al. A cross-national study of violence-related behaviors in adolescents. Arch Pediatr Adolesc Med 2004; 158:539-44.

[38] Pickett W, Molcho M, Elgar FJ, et al. Trends and socioeconomic correlates of adolescent physical fighting in 30 countries. Pediatr 2013;131:e18-26.

[39] Paalman CH, Terwee CB, Jansma EP, et al. Instruments measuring externalizing mental health problems in immigrant ethnic minority youths: A systematic review of measurement properties. PLoS One 2013;8:e63109.

[40] Verhulp EE, Stevens GW, Van de Schoot R, et al. Using the Youth SelfReport internalizing syndrome scales among immigrant adolescents: Testing measurement invariance across groups and over time. Eur J Dev Psychol 2014;11:102-10. 